\title{
EFFICACY OF TRADITIONAL MAIZE (Zea mays L.) SEED STORAGE METHODS IN WESTERN KENYA
}

Wambugu PW ${ }^{1 *}$, Mathenge $\mathrm{PW}^{2}$, Auma $^{\mathrm{E}} \mathrm{O}^{2}$ and HA van Rheenen ${ }^{2}$

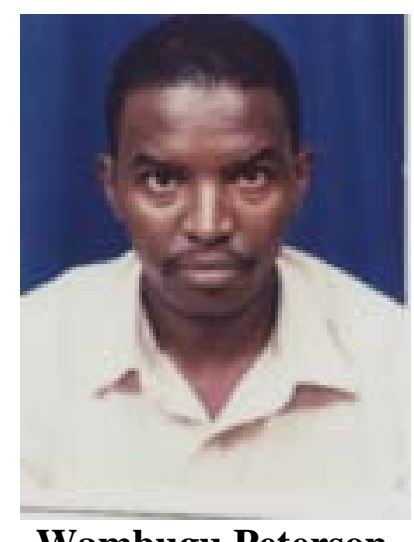

Wambugu Peterson

*Corresponding author email: werupw@yahoo.com.

${ }^{1}$ Present address: Kenya Agricultural Research Institute (KARI), National Genebank of Kenya, P.O. Box 30148, Nairobi, Kenya.

${ }^{2 \& 1}$ Department of Seed, Crop and Horticultural Sciences, Moi University, P.O. Box 1125, Eldoret, Kenya.

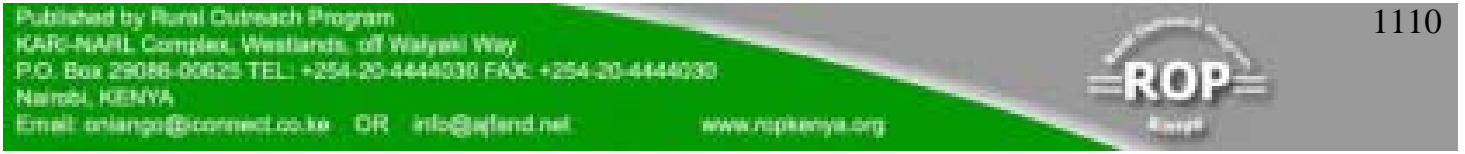




\section{ABSTRACT}

Seed security is key to the attainment of household food security among resource poor farmers in developing countries. In a baseline survey carried out in Siaya and Busia Districts of Western Kenya, storage was identified as a priority problem facing onfarm seed production. During the survey, it was found that about $80 \%$ of the farmers produce and store their own seeds for planting in the next cropping season. During this process of seed saving, farmers reported some decline in seed quality thus leading to poor germination and eventually poor yields. A storage experiment was, therefore, set up with the objective of improving the efficacy of traditional maize seed storage methods in maintaining seed viability and vigour as compared to some improved ones. The traditional methods included hanging cobs over the fireplace and storing in gunny bags with cow dung ash as the seed treatment. These were compared with seed treatment using Mortein Doom ${ }^{\circledR}$, a modern seed protectant and cow dung ash; in both cases seeds were stored in airtight containers. These treatments were applied on two maize varieties: Rachar, a local variety and Maseno Double Cobber, an improved variety and the experiment was carried out in the houses of four farmers. Quality analysis of the seeds was done first before storage and then after three and six months of storage. The results indicate that the traditional methods had the poorest performance. They had significantly lower vigour after three and six months' storage and recorded significantly higher insect damage. Seeds hung above the fireplace had the highest insect damage and this was about 99\% higher than the damage recorded for seeds treated with ash and stored in airtight plastic containers. Seeds hung above the fireplace also had significantly higher moisture content increase. The best treatment was storage in airtight containers with either Mortein Doom ${ }^{\circledR}$ or cow dung ash as the seed treatment. Genetic differences in storability between the 2 varieties were not observed. This study concluded that the principle of airtight, though not new, should be used to design low cost seed storage containers for resource-poor farmers which will result in better seed quality. The study further shows that cow dung which is freely available in most homesteads is a good seed protectant and is effective in maintaining seed quality in storage. Cow dung ash should therefore be combined with air tight storage to increase the seed longevity.

Key words: Cow dung, airtight, seed, viability

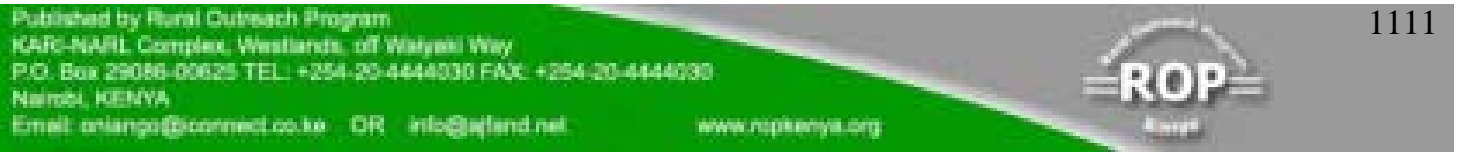




\section{INTRODUCTION}

Maize (Zea mays L.) is the most important cereal in Kenya and is the staple food for over $90 \%$ of the population. About 1.6 million hectares are under maize annually, $80 \%$ of which is owned by smallholder farmers [1]. In the moist mid-altitude zone of western Kenya, which is drought prone, maize is an important crop grown by almost all households in at least one cropping season per year. The area though is infested with striga hermonthica which is a noxious parasitic weed of mainly cereal crops that often leads to $80-100 \%$ yield loss. Due to this and other challenges, the on-farm maize yield is too low to keep up with the rate of population growth, leading to serious food and seed insecurity and poverty $[2,3]$.

Among the causes of seed insecurity in Africa is inadequate facilities and inappropriate methods for seed storage among rural farmers. This impairs the maintenance of sufficient and safe seed resources compounded with poverty, and insufficient technical and financial support [3]. Successful seed storage is key to farmers' seed security and may also enable communities to generate income through collecting, storing and selling seeds. Seed storage problems are partly responsible for farmers' failure to save seeds of non-traditional crops [4]. Poor seed storage conditions have been reported to cause up to $10 \%$ loss in seed quality in the tropics mainly through loss of viability [5, 6].

Seed insecurity in Africa is a recurrent problem which is more acute among the poorest farmers. This problem should, therefore, be addressed as seed security is essential in ensuring increased use of agro biodiversity which would in turn expand the options, opportunities and means available at the rural grassroots level to improve nutrition and health, safeguard the household economic security and enhance sustainable agriculture [3]. It is against this background that this study was initiated. This being an on-farm study, it was important to validate the efficiency of some of the traditional seed storage methods. The overall objective was to improve the capacity of farmers to store and conserve quality seeds in an effort to achieve food and seed security. The efficacy of some traditional seed storage methods and some improved ones were therefore compared. To guide the study, a questionnaire survey was conducted whose objective was to describe the farmer seed management practices during storage and to identify constraints thereof.

\section{MATERIALS AND METHODS}

\section{Study area}

The study was carried out in Siaya and Busia Districts of western Kenya (Fig 1). Busia District receives a mean annual rainfall of $1500 \mathrm{~mm}$ over two seasons a year. The annual mean maximum temperature ranges from 26 to $30^{\circ} \mathrm{C}$, while the annual mean minimum temperature varies from 14 to $18^{\circ} \mathrm{C}$. The altitude varies from 1130$1375 \mathrm{~m}$. The district has 4 agro-ecological zones (AEZs) $-\mathrm{LM}_{1}-\mathrm{LM}_{4}$. Siaya district gets an average annual rainfall of $800-1600 \mathrm{~mm}$ which is bimodal. The mean

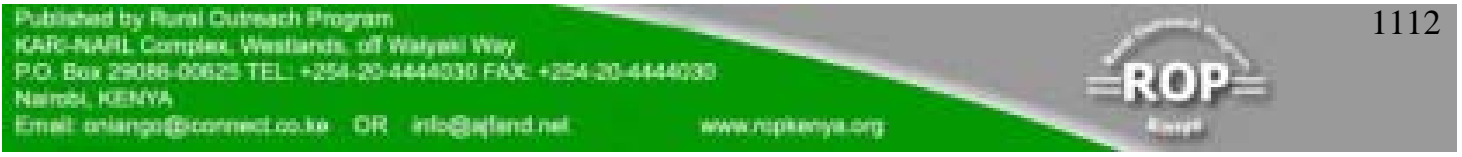


temperature is $21^{\circ} \mathrm{C}$. The altitude in the district ranges from 1140 to $1400 \mathrm{~m}$ above sea level (A.S.L). The district has 5 AEZs - $\mathrm{LM}_{1}-\mathrm{LM}_{5}$ [7].

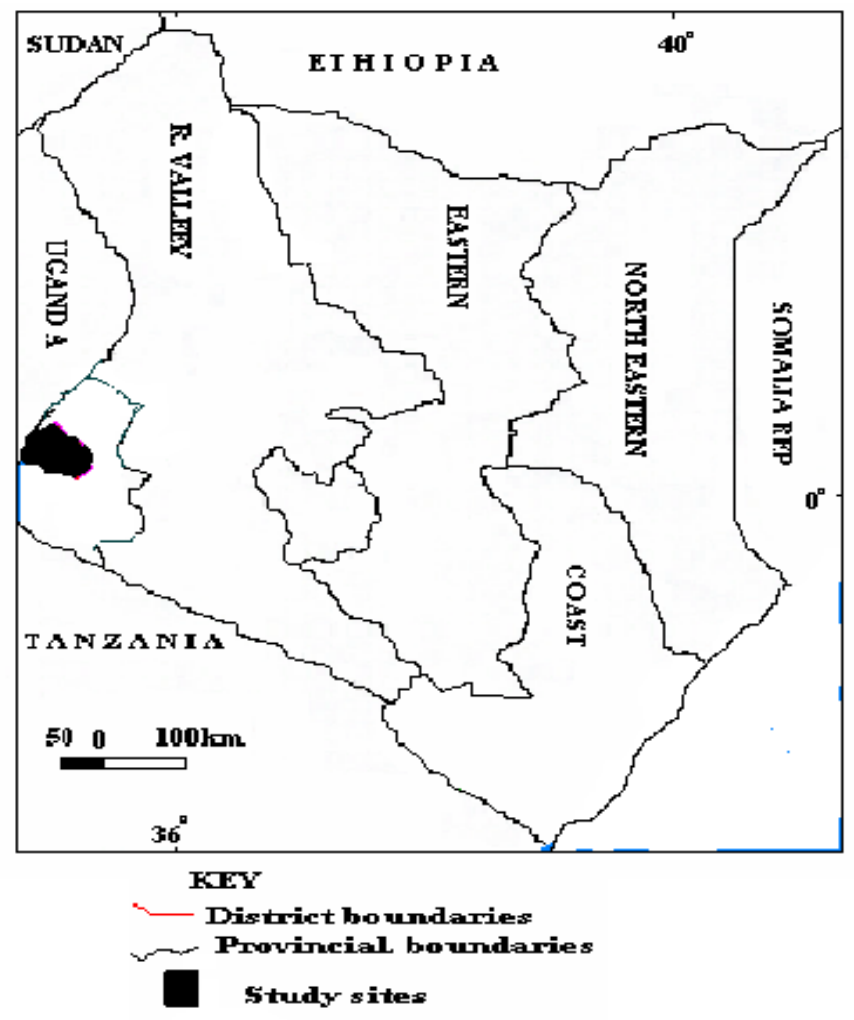

Figure 1: Map of Kenya showing the study sites in Siaya and Busia Districts

\section{The Survey}

This study started with a formal questionnaire survey where seven divisions were selected in the two districts representing different AEZs ranging from $\mathrm{LM}_{1}-\mathrm{LM}_{5}$. The divisions were Nambale, Matayos, Butula and Funyula in Busia District and Ukwala, Uranga and Yala in Siaya District. Before the detailed survey was conducted, reconnaissance visits to the study area were undertaken. Pre-testing of the questionnaire was done by administering the same to about 10 farmers in Matayos Division who had been selected by the Divisional Agricultural Extension Officer. This was done in order to assess the time it would take to administer the questionnaire for each respondent and to see whether it captured all the important issues required in the survey. During the survey, a total of two hundred farmers were interviewed between July and September 2002. A non-random purposive selection method was used to identify the farmers to be interviewed. Identification was mainly done by extension staff in the Ministry of Agriculture and Rural Development (MOARD).

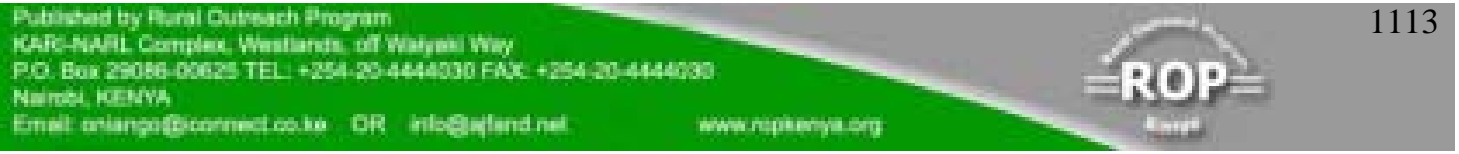


Based on the results of the survey, a storage experiment was conducted as detailed below.

\section{Experimental design}

The experiment was carried out in the houses of four farmers, one farmer each in Yala and Ukwala divisions of Siaya district and Nambale and Funyula divisions of Busia district. A Randomized Complete Block Design (RCBD) with 4 replications was followed with each farmer representing a replication. The study was conducted on two maize varieties; Rachar $\left(\mathrm{V}_{1}\right)$ which is a local variety and Maseno Double Cobber $\left(\mathrm{V}_{2}\right)$. Maseno Double Cobber is a prolific open-pollinated variety (OPV) developed in the 1990s. It is a medium-altitude variety that also does well in higher altitudes and is tolerant to drought conditions in lower altitudes. It doubles the number of cobs and is suitable for roasting as it is sweet. Four different storage methods were tested as shown in Table 1.

The farmers' seed storage method was used as the control.

The quantity of ash and Mortein Doom ${ }^{\circledR}$ used in this study was about 3.3\% and $0.9 \%$ by weight, respectively. The ash used in the study was prepared by burning dried cow dung. Mortein Doom ${ }^{\circledR}$ is a modern commercial seed protectant which is in powder form and is available in the market. Seed quality was determined at the onset of the storage trial and after storage periods of 3 and 6 months.

\section{Laboratory Experiments}

The seeds were tested for electrical conductivity, tetrazolium chloride response, germination in sand, insect damage and moisture content following procedures described below.

\section{Electrical conductivity test}

Electrical conductivity was determined by selecting four samples of 50 seeds from each treatment of each farmer. The seeds were weighed and incubated in $250 \mathrm{ml}$ of distilled water at $20^{\circ} \mathrm{C}$ for 24 hours. The electrical conductivity of equivalent quantity of water was also measured as a control using a Fieldlab-LF conductivity Meter and LF 513T electrode dip-type cell (Schott Gerate Glass Company, Mainz, Germany). The conductivity per gram of seed in $\mu \mathrm{s} / \mathrm{cm} / \mathrm{g}^{-}$at $12 \%$ moisture content in $250 \mathrm{ml}$ of water was then calculated [8].

\section{Tetrazolium test}

Four samples of 25 seeds each were randomly selected from each treatment of each farmer. The seeds were soaked in water at room temperature for 18 hours. Thereafter, the seeds were cut longitudinally through about $2 / 3$ of the endosperm and then soaked in $1 \%$ tetrazolium solution (2, 3, 5-triphenyltetrazolium chloride) at $30^{\circ} \mathrm{C}$ for 3 hours. Subsequently, the seeds were washed in water for about 2 minutes and examined for the staining pattern of the embryo with the help of a hand lens [8]. Based on the staining, the percentage of viable seeds was estimated.

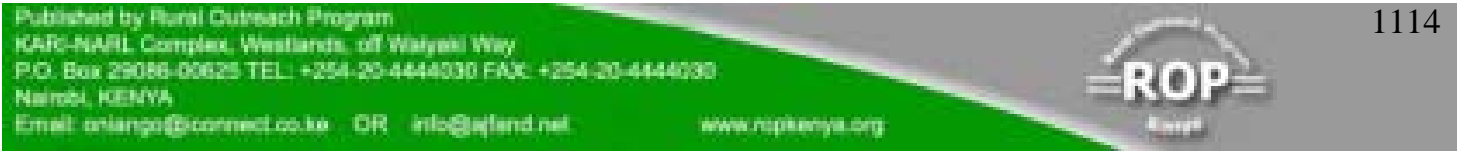




\section{Germination percentage}

Four replicate samples of 100 seeds each were sown in sand and placed in germination chambers at a temperature of $20-30^{\circ} \mathrm{C}$. The seedlings were evaluated after 7 days where they were put into 3 categories: Normal, abnormal and dead seeds. For example, seeds with stunted, retarded, constricted, broken, decayed or missing primary and/or secondary roots were classified as abnormal [9]. Percentage germination was then computed.

\section{Insect damage}

Insect damage was also assessed by the count method. A sample of 200 seeds was randomly taken and the number of insect-damaged and undamaged seeds was determined. The percentage of insect-damaged seed was then calculated.

\section{Moisture content}

Moisture content was measured using a moisture meter, Hydromette G86.

\section{Data analysis}

The effect of storage method on seed viability, insect damage and moisture content over time, was analyzed by ANOVA using the Generalized Linear Model of SPSS version 12.

\section{RESULTS}

\section{Seed storage}

About $78 \%$ of farmers in the study area save and store their own seeds from one season to another (Table 2). These farmers have developed a variety of storage practices. The most common storage methods were gunny bags $(55 \%)$, plastic containers $(24 \%)$ and hanging over the fireplace $(13 \%)$.

During storage, the most common storage treatment was applying cow dung ash $(51 \%)$ and Actellic ${ }^{\circledR}(30 \%)$. About $23 \%$ of the farmers did not treat their seed (Fig. 2). 


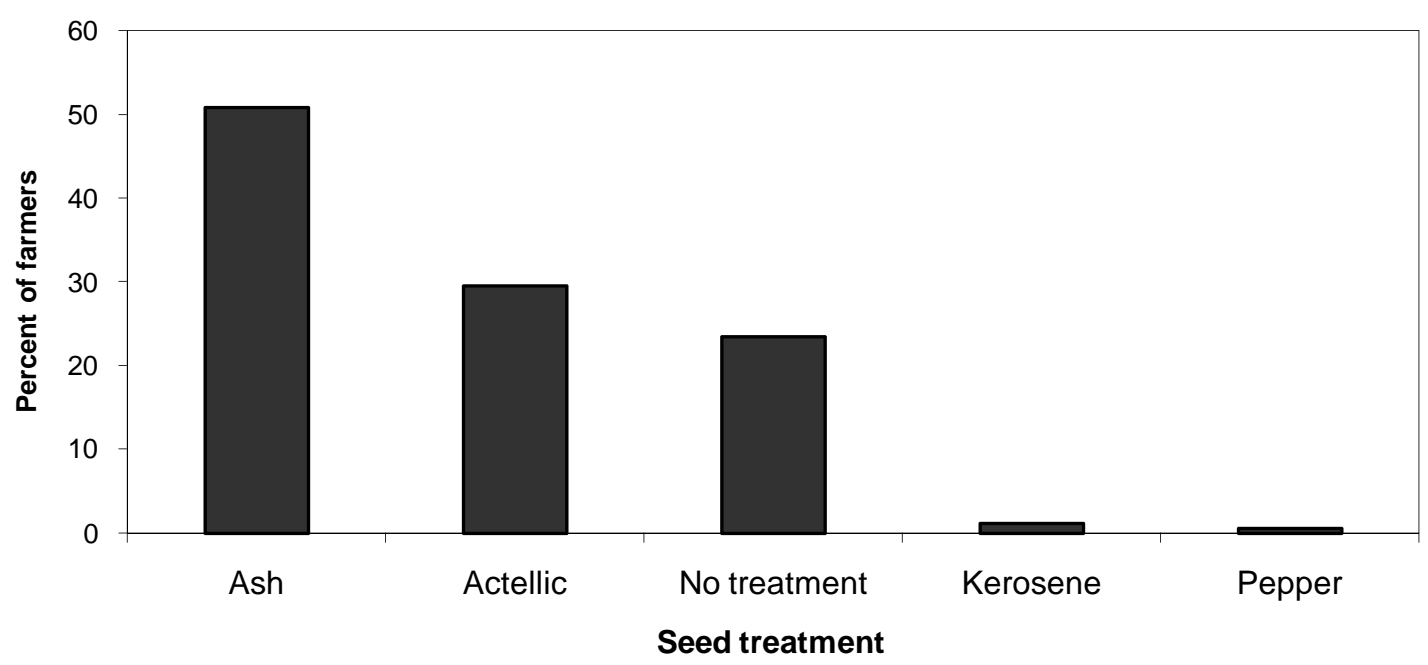

Figure 2: Seed treatments used by farmers during storage $(n=179)$

\section{Viability}

The results of the study showed that there were highly significant differences in vigour after 3 and 6 months storage. An analysis of seeds stored for 3 and 6 months revealed highly significant differences in both vigour and viability. Figures 3 and 4 show that seeds stored in airtight containers had higher vigour and viability than those stored in gunny bags and hung above the fireplace.

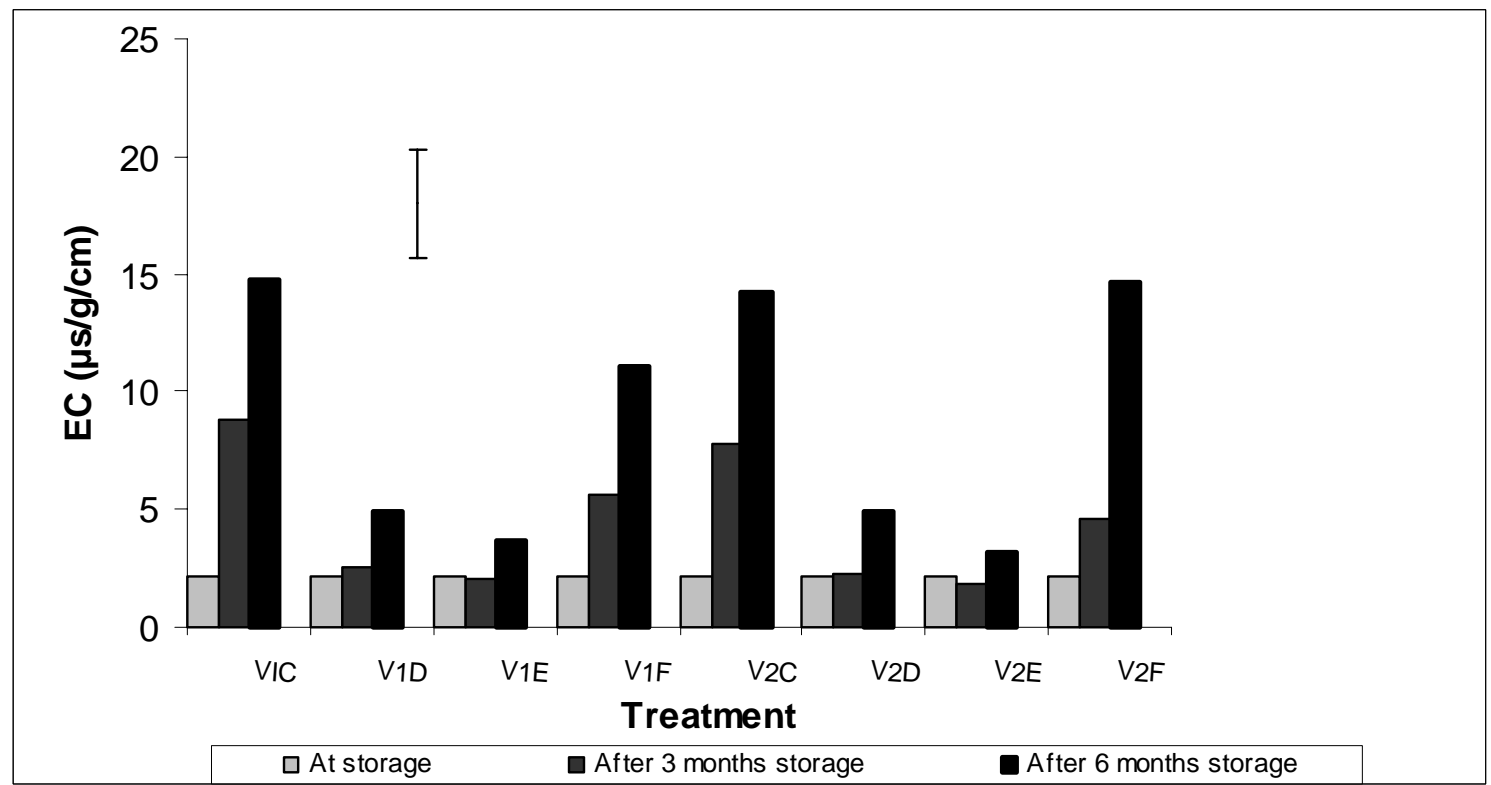

Figure 3: Electrical Conductivity $(\mu \mathrm{s} / \mathrm{g} / \mathrm{cm})$ after 0,3 and 6 months' storage. Bar represents LSD. A description of the treatments coded above is provided in Table 4 


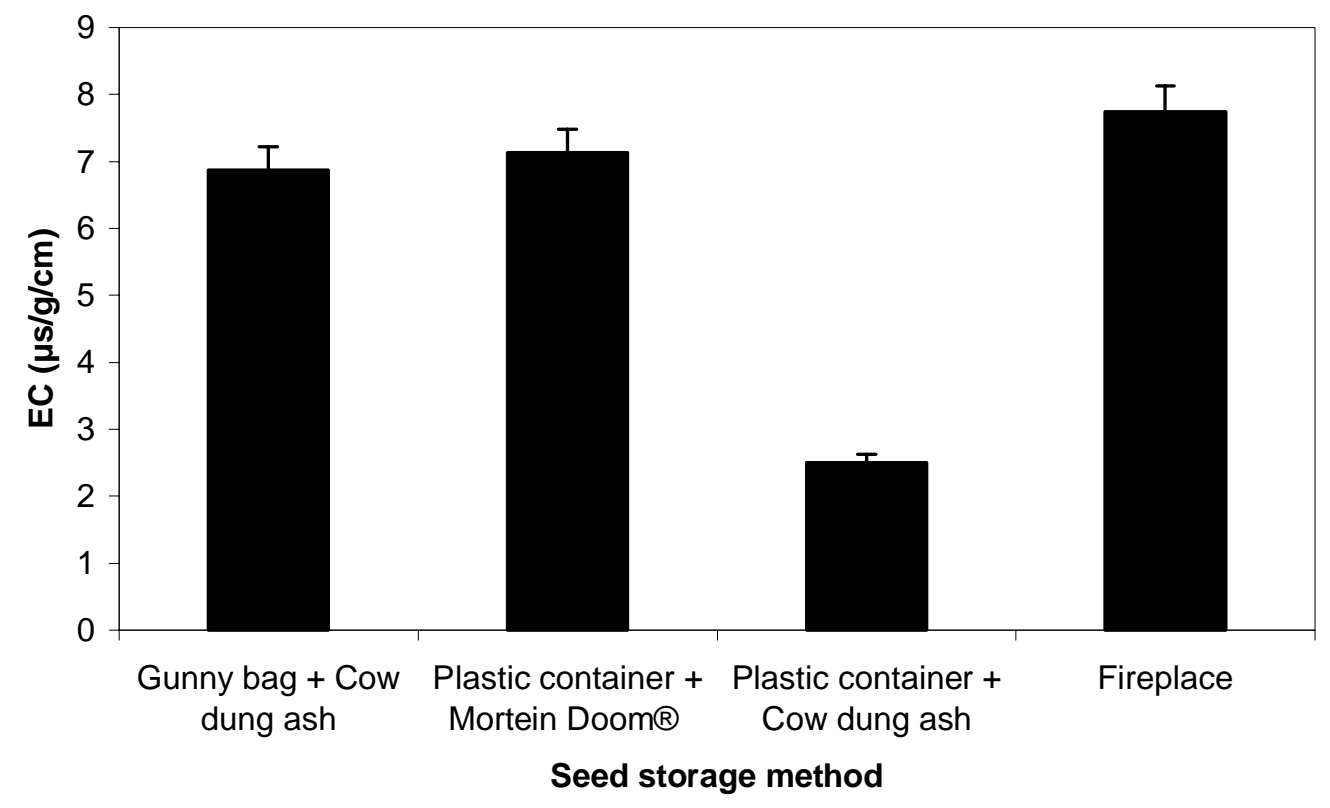

Figure 4: Electrical conductivity for different storage methods during a-6 month storage period. High electrical conductivity values represent low seed vigour

Seeds stored in plastic containers and treated with cow dung ash had the highest seed vigour while those hung above the fireplace had the lowest (Fig. 4). Storage of seeds in gunny bags with cow dung ash as a seed treatment method and hanging cobs over the fireplace exhibited the highest decline in seed viability after three and six months storage (Fig. 5). 


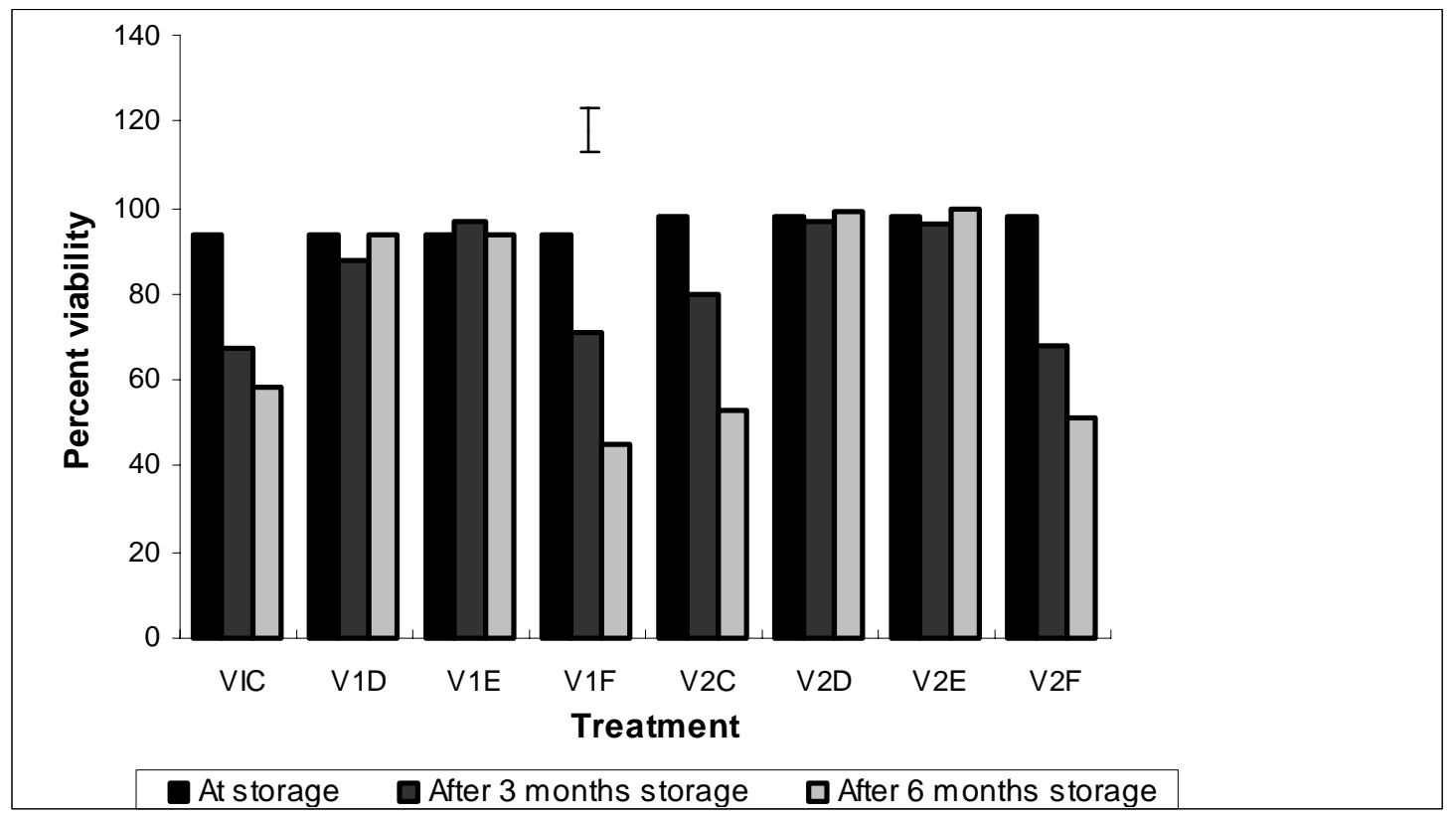

Figure 5: Percent viability during a-6 month storage period. Bar represents LSD. A description of the treatments coded above is provided in Table 4

The lowest germination capacity was recorded by seeds hung above the fireplace while those stored in airtight containers had the highest. The effect of cow dung ash and Mortein Doom ${ }^{\circledR}$ in maintaining viability was almost the same when seeds were stored in airtight containers (Fig. 6). 


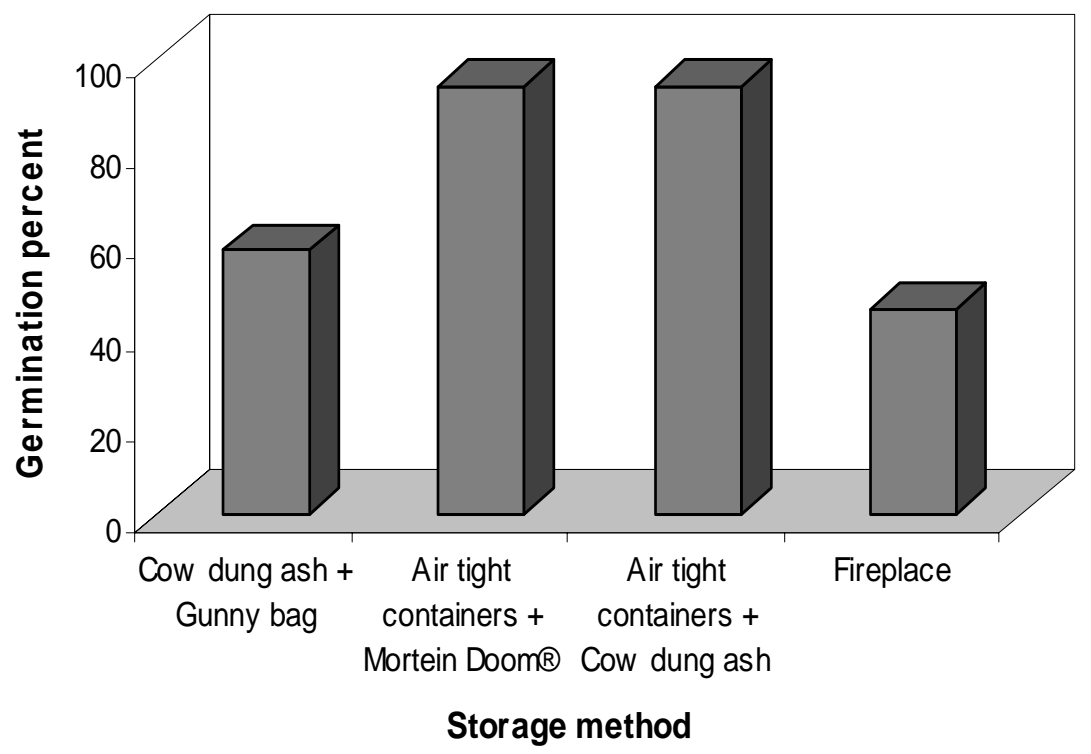

\section{Figure 6: Germination percentage with different seed treatment methods after a-6 month storage period.}

\section{Moisture content}

Seeds hung above the fireplace and those stored in gunny bags had significantly higher moisture content increases than those stored in airtight containers after a storage period of 6 months (Table 2). Varietal differences were, however, not significant.

\section{Insect damage}

The traditional seed storage methods recorded significantly higher insect damage than storage in airtight containers (Table 3). Seeds hung above the fireplace had the highest insect damage and this was about 99\% higher than the damage recorded for seeds treated with ash and stored in airtight plastic containers. Varietal differences with respect to insect damage were not significant.

\section{DISCUSSION}

While it is generally known that airtight storage is not new and has been found to be superior to non-airtight storage, this study is particularly useful and has merits since it encompasses ethnic practices that have not been properly studied in the region. The results of this study generally confirm most of the findings in literature but there are notable differences. While the traditional methods of seed storage have been considered as being highly effective $[10,11]$, the results of this study clearly contradict this. 


\section{Hanging seeds above the fireplace}

Figures 4 and 6 show that after 6 months of storage, seeds stored in gunny bags and treated with cow dung ash and those stored above the fireplace had very low vigour and viability. These traditional methods also recorded significantly higher insect damage (Table 3). This is in agreement with the observation of Pats [12] who reported that smoking (storage above the fireplace) was not effective in reducing insect damage. Farmers in South Africa also reported that seeds stored above the fireplace had inferior seed quality which led to low germination and poor yields [13].

On the contrary, other authors have noted that smoking keeps the seeds dry and reduces insect and disease damage [10,14]. Under Philippine conditions it was found that the combined benefits of fumigation and drying, afforded by smoking, extended the viability and storability of seed grains by six months [15]. This contradiction in results can partly be attributed to the differences in the manner in which smoking was done. The seed moisture content at the time of storage, frequency of lighting fires, temperature and humidity at the storage place are possible factors that could affect the outcome of the storage methods. In Kenya, the majority of farmers do not dry their seeds sufficiently prior to storage above the fireplace (Personal observation). This may, therefore, negate the effects of smoking as drying seeds at high moisture content is detrimental to seed viability and longevity. The heat generated by smoke from the hearth may have caused the low seed vigour. The roofing material under which smoking is done is also a possible factor on the efficacy of smoking as was reported by Muli et al. [16]. These authors found that smoking is less effective under roofs of corrugated iron sheets than under grass or palm leaf roofs. Corrugated iron sheets generate more heat inside the house than other types of roofs such as grass thatched ones. The present study was conducted in a corrugated roof house. Temperature is probably the main factor involved in determining the effectiveness of smoking.

Traditionally, smoke is used to minimize insect damage as well as to reduce moisture content to a suitable level $[10,11,17]$. It has been argued that the combined effect of smoke and high temperatures during smoking has a permanent effect on seed testa which prevents oxygen rise around the embryo during storage thus increasing hermetic conditions as far as the embryo is concerned [11].

\section{Storage of seeds using ash}

Often, ash is effective in controlling insect damage [10, 18, 19] but this study contradicts this. Ash is used both as an inert filler and for its other negative effects on insects. As an inert filler, ash works by filling up the space around the seed and impeding the movement of insects as well as, in sealed containers, reducing the volume of air available to the insects for respiration. Ash has been reported to damage the cuticle of insects causing them to dehydrate and also has detrimental effect on egg development $[10,17,18]$. Table 3 shows that seeds treated with ash and stored in gunny bags had the second highest insect damage after those stored over the fireplace. In addition, viability and vigour were also low as shown in Figures 4 and 2, respectively. These differences in the effectiveness of ash can possibly be attributed to the kind and amount of ash used and method and time of application. Thirty percent

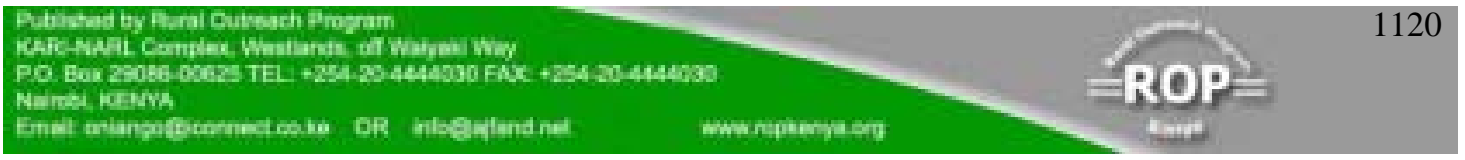


of ashes by weight and $25-50 \%$ by volume were recommended by Wright et al. [17] and Almekinders and Louwaars [10], respectively. The quantity of ash used in this study was $3.3 \%$ by weight. The application of ash should be done well before infestation by insects begins. The effectiveness of ash in reducing insect damage may be diminished by the use of gunny bags which do not give much protection from either to insects or rodents. The ash should be dry and fresh [19].

Although ash is commonly used in seed storage as reported in various reports $[10,17$, 18], farmers differ widely in the way they use it, especially in the proportions of ash to grains. In Cameroon, for example, some farmers dusted their cowpeas lightly with ash, others used a large amount of ash over the grains while still others used alternate layers of cowpeas and ash [20]. This has led to varied and sometimes contradictory reports on the effectiveness of ash during storage. Given the uncertainty about the effectiveness of ash as a grain protectant, there is need to develop procedures on how to use ash in storage. Research has shown that ash can indeed protect seeds from pests but with some limitation [20]. In protecting cowpeas seeds, a standard procedure was developed by scientists in Cameroon. Under this technology, equal volumes of sieved ash and grain should be mixed and put in a container. The ash/grain mixture should then be covered with a $3 \mathrm{~cm}$ layer of ash. Grain kept in this manner can be kept long for long periods of time with minimal losses.

\section{Storage in airtight containers}

Storage of seeds in airtight plastic containers emerged as the best treatment in maintaining viability and vigour and in reducing insect damage. This method was significantly different from open storage, for example hanging cobs over the fireplace and storage in gunny bags (Tables 2 and 3). However, differences between ash and Mortein Doom ${ }^{\circledR}$ were not significant when seeds were stored in airtight containers. That locally available ash was as effective as Mortein Doom ${ }^{\circledR}$ is particularly encouraging. Both methods were quite effective in reducing insect damage and maintaining seed vigour and viability. A similar observation was made in a similar study where it was reported that locally available sand and ash were as effective as Actellic $^{\circledR}[18]$. Airtight storage provides excellent insect control and prevents the grain from re-absorbing moisture from humid outside air. The insects suffocate as soon as the oxygen in the container is used up.

Table 2 shows that the farmers' methods of storing seeds in the open experienced significantly higher moisture content increase than in closed storage. This moisture increase may reduce the longevity of seeds since it is generally known that every $1 \%$ increase in seed moisture content reduces the storage period by half [21]. The increase in moisture content by seeds stored in airtight containers was unexpected. However, this could have been due to the fact that seeds did not fill the containers completely and hence the air in the headspace could have had some moisture which may have been absorbed by the seeds. It is advisable to fill the containers completely [10]. 


\section{Genetic differences in storability}

Numerous accounts have suggested that some varieties of maize and other species store better than others under similar conditions. Just like other characters, seed longevity is in part genetically determined [22]. Farmers believe that their local varieties store better than improved varieties [23]. However, such differences were not observed in the present study.

\section{CONCLUSIONS}

The results of this study have shown that with some slight improvements, traditional seed storage methods can maintain the quality and viability of seeds. The combination of cow dung ash and air tight storage in plastic containers led to significant reduction in seed deterioration. Although airtight storage is not new, the principle behind it needs to be used in designing low cost seed storage containers for resource-poor farmers which will allow them to save enough seeds of high quality for future planting. This technology should then be combined with other traditional seed storage methods such as the use of ash in order to reduce seed deterioration in storage.

\section{ACKNOWLEDGEMENT}

The authors acknowledge with thanks the assistance from the Rockefeller Foundation through Forum for Agricultural Resource Husbandry (FORUM) for providing funds to carry out this study. Thanks are also due to participating farmers in Siaya and Busia Districts for allowing us to use their houses for the study and sharing their knowledge and ideas. Logistical support by Moi University is also greatly acknowledged. 
Table 1: Treatments incorporated in a storage experiment carried out in western Kenya

\begin{tabular}{ll}
\hline CODE & TREATMENT \\
\hline C & Storage in gunny bags $\dagger$ placed on the floor with cow dung ash as seed \\
& treatment \\
D & Seeds treated with Mortein Doom ${ }^{\circledast}$ and stored in airtight plastic \\
E & containers \\
F & Seeds treated with cow dung ash and stored in airtight plastic containers \\
& Maize cobs hung over the fireplace \\
\hline
\end{tabular}

$\dagger$ A gunny bag is a sack made of gunny or burlap and is used for storing or transporting coarse commodities such as grains

Table 2: Percentage of farmers using seeds from different sources

\begin{tabular}{ll}
\hline Source & Percent of farmers $(\mathrm{n}=200)$ \\
\hline Own seed & 78 \\
Certified seeds & 18 \\
Market & 9 \\
Neighbours & 3 \\
\hline
\end{tabular}


Table 3: Percentage of farmers using different seed storage methods

\begin{tabular}{ll}
\hline Method & Percent of farmers \\
\hline Gunny bags & 54.9 \\
Plastic containers & 24.1 \\
Hanging over the fireplace & 12.8 \\
Hanging from the roof & 7.7 \\
Granary & 3.1 \\
Others* & 9.7 \\
\hline
\end{tabular}

*These include hanging seeds on trees, storage in earthenware pots and burying in the ground

Table 4: Description of treatment as coded in Figures 5.1 and 5.3

\begin{tabular}{ll}
\hline CODE & TREATMENT \\
\hline V1C & Local variety stored in gunny bags and treated with cow dung ash \\
V1D & Local variety treated with Mortein Doom $^{\circledR}$ and stored in airtight containers \\
V1E & Local variety treated with cow dung ash and stored in airtight containers \\
V1F & Local variety hung above the fireplace \\
V2C & Maseno Double Cobber stored in gunny bags and treated with cow dung ash \\
V2D & Maseno Double Cobber treated with Mortein Doom ${ }^{\circledR}$ and stored in airtight \\
V2E & containers \\
V2F & Maseno Double Cobber treated with cow dung ash and stored in airtight \\
& containers \\
& Maseno Double Cobber hung above the fireplace \\
\hline
\end{tabular}


Table 5: Moisture content increase (\%) for various storage methods after 6 months storage

\begin{tabular}{llll}
\hline & \multicolumn{2}{c}{ Variety } & \\
\cline { 2 - 3 } Treatment & Rachar & Maseno D.C & Mean $\dagger$ \\
\hline Gunny bag + cow dung ash & 13.8 & 13.8 & $13.8 \mathrm{a}$ \\
Doom + Plastic container & 12.8 & 12.9 & $12.8 \mathrm{~b}$ \\
Ash + Plastic container & 12.9 & 12.4 & $12.6 \mathrm{~b}$ \\
Fireplace & 13.9 & 13.9 & $13.9 \mathrm{a}$ \\
Mean $\dagger$ & 13.3 & 13.2 & \\
& & & \\
G. Mean & 13.3 & & \\
SE & 0.1 & & \\
P=0.05 & 0.3 & \\
\hline
\end{tabular}

$†$ Means followed by the same letter within a column or row are not significantly different according to $\mathrm{p}=0.05$. 


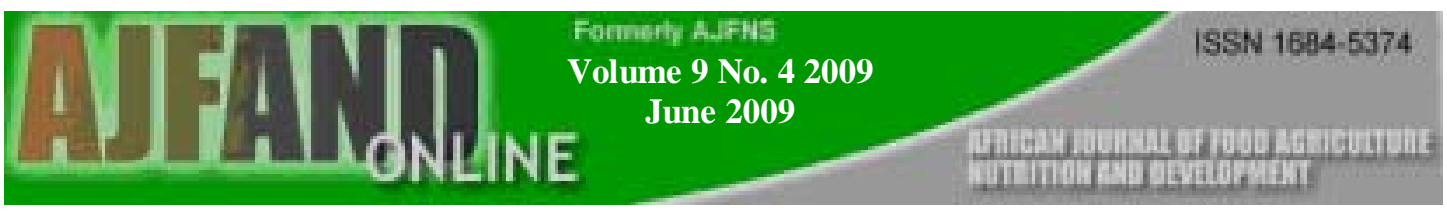

Table 6: Insect damage (\%) seeds observed with various methods of seed storage

\begin{tabular}{llll}
\hline & \multicolumn{2}{l}{ Variety } & \\
\cline { 2 - 3 } Treatment & Rachar & Maseno D.C & Mean $\dagger$ \\
\hline Gunny bag + cow dung ash & 56.3 & 37.6 & $46.9 \mathrm{ab}$ \\
Doom + Plastic container & 1.1 & 1.6 & $1.4 \mathrm{c}$ \\
Ash + Plastic container & 0.9 & 0.3 & $0.6 \mathrm{c}$ \\
Fireplace & 54.8 & 54.3 & $54.5 \mathrm{a}$ \\
Mean $\dagger$ & $28.3 \mathrm{a}$ & $23.4 \mathrm{a}$ & \\
& & & \\
G. Mean & & & \\
SE & 25.8 & \\
P= 0.05 & 5.8 & \\
\hline
\end{tabular}

$†$ Means followed by the same letter within a column or row are not significantly different according to $\mathrm{p}=0.05$ 


\section{REFERENCES}

1. Kamidi M, Cheruiyot D, Osore $\mathbf{P}$ and $\mathbf{G}$ Barasa Verification of the effect of organic manures and inorganic fertilizers on the yield of maize. In: Tenywa, J.S. Zake, J.Y.K., Ebanyat, P., Semalulu, O. and Nkalubo, S.T. (eds). A key to sustainable land use. Proceedings of the $17^{\text {th }}$ conference of the Soil Science Society of East Africa, Kampala, Uganda, 6-10 September 1999.

2 Odendo $M$, de Groote $H$ and OM Odongo Assessment of farmers' preferences and constraints to maize production in the moist mid-altitude zone of Western Kenya. African Crop Science Conference Proceedings, 1999; 5: 769-775.

3 Gari JA Agro-biodiversity strategies to Combat Food Security and HIV/AIDS Impact in Rural Africa: Advancing grassroots responses for nutrition, health and sustainable livelihoods. FAO Population and Development Service, Rome, Italy 2004.

4 Delouche JC Seed quality guidelines for the small farmer. In: Improved seed for the small farmer. Conference proceedings. CIAT (Centro Internacional de Agricultura Tropical), Cali, Colombia, 1982:26-29.

5 Louwaars NP Integrated Seed Supply: a flexible approach. In. Hanson, J. (ed). Seed production by smallholder farmers. Proceedings of the ILCA/ICARDA Research Planning Workshop held in ILCA, Addis Ababa, Ethiopia, 13-15 June 1994. 58pp.

6 Gwinner J, Harnisch R and O Mueck Manual of handling and. conservation of seeds after harvest. GTZ, Eschborn, Germany, 1991.

7 Jaetzold R and H Schmidt Farm Management Handbook of Kenya: Natural conditions and Farm Management Information Vol. II/A. Published by Ministry of Agriculture, Kenya, in Collaboration with the German Agricultural Team (GAT) of the German Technical Cooperation (GTZ), 1982: p.397.

8 ISTA. Handbook of vigour methods. $3^{\text {rd }}$ Edition. The International Seed Testing Association, Zurich, 1995.

9 ISTA. International Rules for Seed Testing. $4^{\text {th }}$ Edition. The International Seed Testing Association, Zurich, 2004.

10 Almekinders CJM and NP Louwaars Farmers' seed production. New approaches and practices. IT publications, London, 1999: p 290.

11 Modi AT Short term preservation of maize landrace seed and taro propagules using indigenous storage methods. South African Journal of Botany; 2004: 70(1): 16-23.

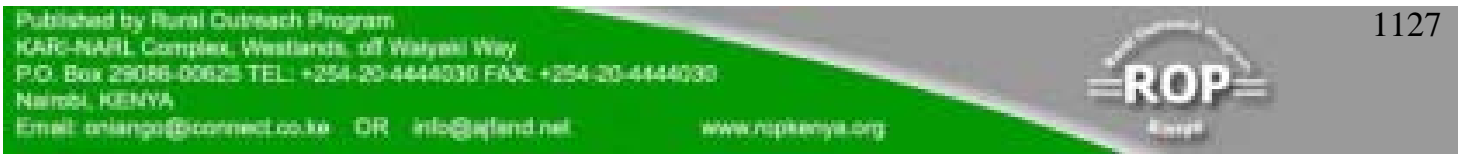


12 Pats P A Survey on maize and potato storage in Kenya with particular reference to post harvest losses caused by insects. http://www.sII..bibul.slu.se, 1985.

13 Thamaga-Chitja JM, Hendriks SL, Ortmann GF and M Green Impact of Maize Storage on Rural Household Food Security in Northern KwaZulu Natal. Family Ecology and Consumer Science, 2004; 32: 8 - 15.

14 Kones S Traditional Storage of Farm Products. ILEIA Newsletter, 1993; 9(3): 12-13.

15 De Pedro RC Jr and JM Villasin Seed grain pest control cum storage for small scale farmers: the case of the "kurob" (storage facility) model. Anniversary and Annual Convention of the Pest Control Council of the Philippines, Davao City, Philippines. 5-8 May, 1987: 1p.

16 Muli MB, Gethi JG and GM Kamau The response of Maize (Zea mays L.) varieties to fertilizer, processing and storage methods in Coastal Kenya. In: Mukisira, E.A., Kiriro, F.H., Wamuongo, J.W., Wamae, L.W., Muriithi, F.M. and Wasike, W. (eds). Collaborative and Participatory Research for Sustainably Improved Livelihoods. Proceedings of the $7^{\text {th }}$ KARI biennial scientific conference $13-17^{\text {th }}$ November, 2000.

17 Wright M, Donaldson T, Cromwell $\mathbf{E}$ and $\mathbf{J}$ New The retention and care of seeds by small-scale farmers. NRI Report R2103, 1994.

18 Grant S Saving seed in Senegal. www.fadr.msu.ru/rodale/agsieve/txt/vol3/5/a1.html, 1990; (Accessed on 06/02/2009).

19 Naito A Low Cost Technology for Controlling Soybean Insect Pests in Indonesia. 1999. www.fftc.agnet.org.(Accessed on 03/11/2005).

20 Wolfson JL, Shade RE, Mentzer PE and LL Murdock Efficacy of ash for controlling infestations of Callosobruchus maculates (F.) (Coleoptera: Bruchidae) in stored cowpeas. Journal of Stored Products Research, 1991; 27 (4): 239-243.

21 Harrington JF Seed storage longevity. In: Kozlowski TT, ed. Seed biology, volume III. New York: Academic Press, 1972, pp 142-245.

22 Priestly DA Seed Ageing. Cornell Univ. press, Ithaca, NY. 1986.

23 Hassan RM, Njoroge $\mathbf{K}$, Njore M, Otsyulla $\mathbf{R}$ and A Laboso Adoption patterns and performance of improved maize in Kenya. In. R.M. Hassan (ed), Maize Technology Development and Transfer. A GIS Application for Research Planning in Kenya. Wallingford, UK: CAB International, CIMMYT and Kenya Agricultural Reseacrh Institute, 1998:107-136.

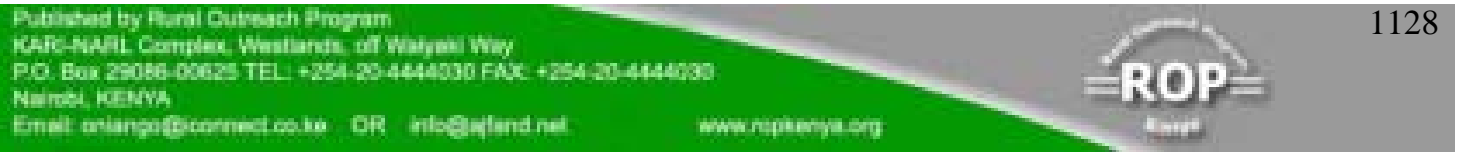

